\title{
The Joule-Thomson Effect for Refrigerants with Dopants of the Fullerenes and Carbon Nanotubes
}

\author{
M. Petrenko, S. Artemenko ${ }^{\bowtie}$, D. Nikitin \\ Odessa National Academy of Food Technologies, 112, Kanatna Str., Odessa, 65039, Ukraine \\ $\triangle$ e-mail: sergey.artemenko@gmail.com
}

The importance of thermodynamic and phase behavior of working fluids embedded with nanostructured materials is fundamental to new nanotechnology applications. The fullerenes $\left(C_{60}\right)$ and carbon nanotubes $(C N T)$ adding to refrigerants change their thermodynamic properties the Joule - Thomson effect such as dislocation of critical point, gas - liquid equilibria shift at alias. Algorithm of refrigerant thermodynamic property calculations based on the NIST (National Institute of Standards and Technologies) equation of state at different carbon nanotube concentrations is proposed. Thermodynamic properties of carbon dioxide in the $C_{60}$ and CNT presence are given. Considering the extremely large number of different both nanoparticle types and reference fluids, it is obvious that there is need for developing theoretically sound methods of the prompt estimation thermodynamic properties and phase equilibria for emerging working media. The effect of nanoparticles on the critical point shift for classical fluids doped by nanoparticles is examined. The regular and singular parts of thermodynamic surface of reference fluid and nanofluid (volume nanoparticle concentration < 5\%) are suggested to coincide in the reduced form. The shift of critical point for nanoliquids of industrial interest is theoretically predicted. Results of calculations of phase equilibria for some nanofluids are described.

Keywords: fullerene; carbon nanotubes; carbon dioxide; Joule-Thomson effects; nanofluids; saturation curve; thermodynamic properties.

\section{Ефект Джоуля-Томсона в холодоагентах при добавці фулеренів і вуглецевих нанотрубок}

\author{
М. О. Петренко, С.В. Артеменко, Д.М. Нікімін
}

Одеська національна академія харчових технологій, вул. Канатна, 112, м. Одеса, 65039, Україна

\begin{abstract}
Важливість термодинамічної та фазової поведінки робочих рідин, щуо вбудовані наноструктурні матеріали, $\epsilon$ основою нових застосувань нанотехнологій. Фулерени $\left(C_{60}\right)$ i вуглецеві нанотрубки (CNT), щзо додаються до холодоагентів, змінюють їх термодинамічні властивості, включаючи серед ефекти Джоуля - Томсона, дислокацію критичної точки, здвиг рівноваги газ - рідина. Запропоновано алгоритм розрахунку термодинамічних властивостей холодоагенту на основі рівняння стану NIST (National Institute of Standards and Technologies) при різних концентраціях фулеренів та вуглецевих нанотрубок. Наведено термодинамічні властивості вуглекислого газу в присутності фулеренів та карбонових нанотрубок. Враховуючи надзвичайно велику кількість різних типів наночастинок та еталонних рідин, очевидно, щзо існує потреба в розробиі теоретично обтрунтованих методів оперативної оцінки термодинамічних властивостей та фазових рівноваг для нових робочих середовищ. Запропоновані регулярні та сингулярні частини термодинамічної поверхні референтної рідини та нанофлюїда (концентрація наночастинок у кількості <5\%) у зведеному вигляді. Теоретично передбачено зміщення критичної точки для нанорідин промислового інтересу. Описано результати розрахунків фазових рівноваг деяких нанофлюїдів.
\end{abstract}

Ключові слова: фулерен; вуглечеві нанотрубки; вуглекислий газ; ефект Джоуля - Томсона; нанофлюїди; лінія насичення; термодинамічні властивості.

(C) The Author(s) 2018. This article is an open access publication

This work is licensed under the Creative Commons Attribution 4.0 International License (CC BY) http://creativecommons.org/licenses/by/4.0/

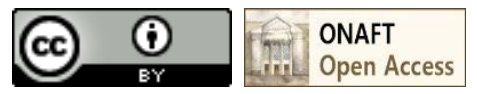

\section{Introduction}

Nanofluids (NF) - solutions of nanoparticles, whose sizes range from 20 to $100 \AA$, are objects of intensive research, thanks to previously unknown effects and an anomalous increase in the thermal conductivity. The great interest in studying the behavior of nanofluids is explained by a wide range of applications: from production and 
energy conversion, transport of oil, refrigeration and air conditioning to electronics, the textile industry and paper production. According to the ratings agency Thomson Reuters, research in the field of nanofluids refers to the "leading edge of research".

The subject of research is the effect of nanostructured material additives on the thermophysical properties and efficiency of working fluids and heat transfer media in energy conversion systems. Development of scientific and technical bases for the implementation of new nanofluids in the heat and power systems. Research methods mathematical modeling of the thermophysical properties of working and heat transfer media, neural network methods for predicting the thermodynamic efficiency of unexplored substances, laboratory experiments, comparing and analyzing the results of numerical simulation with the results of experimental studies. Scientific novelty of the results given in the work.

The following new scientific results were obtained: for the first time, an approach to modeling the thermodynamic characteristics of classical working fluids and coolants with the addition of nanostructured materials based on the thermodynamic similarity of nano- and near-critical fluids was developed and presented. The published literature reviews cover a wide range of applications and properties of nanofluids [1-12]. Key features of nanoparticles include the nonlinear relationship between the thermophysical properties and the bulk concentration of nanoparticles [1], as well as the significant intensification of critical heat fluxes at boiling [2-5]. The use of NF allows you to create a new class of working fluids and coolants for various technological applications, achieving an increase in energy efficiency, lower operating cost, size reduction and reduction of environmental pollution [6 - 12]. Examples of successful application of nanofluids for solving practical problems include [1-12]:

- engine cooling;

- additives in lubricating oils;

- coolants in shirts diesel - generators;

- heating and cooling buildings;

- cooling media in electronics;

- additives in transformer oil;

- cooling media for nuclear reactors;

- solar systems for heating;

- artificial cold (refrigerator chillers);

- military equipment;

- space;

- cooling of high-power lasers;

- biomedical applications.

Two aspects attract industry attention to the introduction of nanofluids - the increase in thermal conductivity and the intensification of convective heat transfer processes as compared with conventional heat transfer media.

Thus, the topic of this study, in which scientific and technical approaches are being developed, is

to solve a number of important problems of technical thermal physics and power engineering,

to increase the efficiency of energy conversion systems using a promising class of working fluids and heat carriers nanofluids,

to search for working fluids that reduce the compression pressure in $\mathrm{CO}_{2}$ compressors.
As an objective we also consider ways to intensify the processes of energy and momentum transfer in microchannels in the flow of nanofluids through nano edges and to compare the effectiveness of hydrodynamic processes with microstructural elements.

The main goal of this work is to evaluate the addition of nanostructured materials and its impact to changes in the thermodynamic properties of refrigerants. As a system, on which the approach to determining the thermodynamic properties of refrigerants with nanostructured materials is tested, a mixture of carbon dioxide is considered - R744 with fullerene and carbon nanotubes.

\section{Impact of nanoparticles on the critical point shift}

A critical point is the singular point of the pressuredensity-temperature surface that designates conditions under which a liquid and its vapor phase can coexist. Knowledge of critical point (line) gives information about thermodynamic behavior of pure substance (binary mixture). Nanoparticles change the intermolecular interactions between nanofluid components and shift the location of singularities. It is suggested that the liquids with small impurities do not violate the corresponding state principle and the dimensionless thermodynamic surfaces of reference liquid and nanofluid are coinciding [5], [6].

Estimation of the change for $\mathrm{CO}_{2}$ critical point with different: CNT - Fig. 1a, fullerenes - Fig. 1b.

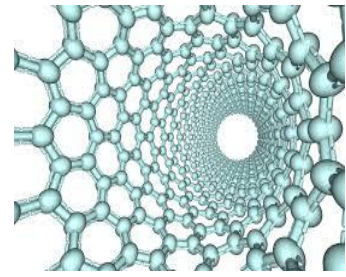

a) $\rho_{C N T}=1330 \mathrm{~kg} / \mathrm{m}^{3}$

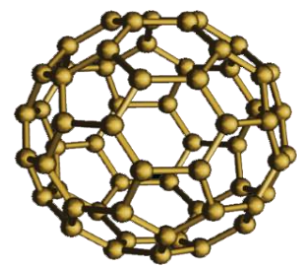

b) $\rho_{C 60}=1650 \mathrm{~kg} / \mathrm{m}^{3}$
Figure 1 - The bulk density of the CNT and $C_{60}$ nanoparticles

The portrait of thermodynamic behavior near critical point for selected fluids was obtained via application of the fundamental equations of state [7, 8]. The variations of critical temperature and density after adding of different nanoparticles are provided in Table 1 and in Figs. 1 - 3. The growth of nanoparticle concentration leads to insignificant change of critical temperature for the $\mathrm{CO}_{2}$ with graphene derivatives nanoliquid.

Table 1 - Effects of CNT and $\mathrm{C}_{60}$ on the shift of critical temperature $\left(\Delta T_{c}=T_{c n f}-T_{c C O 2}\right)$ and density $\left(\Delta \rho_{c}=\rho_{c n f}\right.$ $\left.\rho_{c \mathrm{CO} 2}\right)$

\begin{tabular}{|l|c|c|c|c|}
\hline $\begin{array}{l}\text { Napo- } \\
\text { particles }\end{array}$ & $\begin{array}{c}\Delta \rho_{c}, \\
\mathrm{~kg} / \mathrm{m}^{3}\end{array}$ & $\begin{array}{c}\Delta \rho_{c}, \\
\mathrm{~kg} / \mathrm{m}^{3}\end{array}$ & $\begin{array}{c}\Delta T c, K \\
\varphi=1 \%\end{array}$ & $\begin{array}{c}\Delta T c, K \\
\varphi=5 \%\end{array}$ \\
\hline $\mathrm{CNT}$ & 5.7 & 22.6 & 0.01 & 0.11 \\
\hline $\mathrm{C}_{60}$ & 7.5 & 33.2 & 0.01 & 0.13 \\
\hline
\end{tabular}




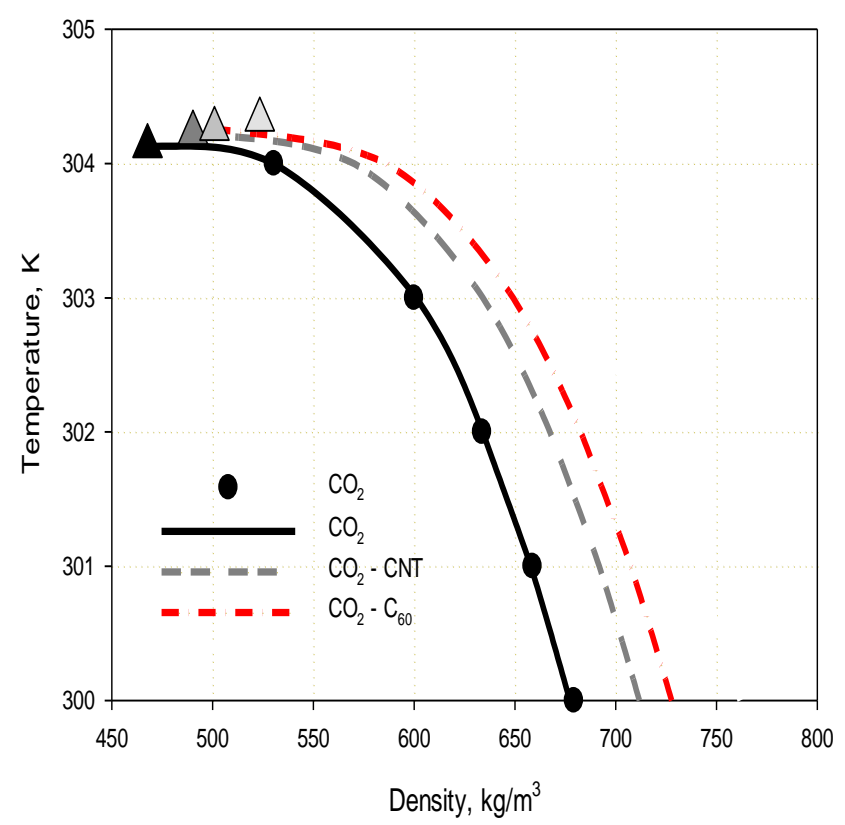

Figure 2 - Effects of CNT and $C_{60}$ doping on position the carbon dioxide critical temperature (triangles) and liquidvapor transition

The critical point identifies the thermodynamic behavior of a pure substance in a wide range of state parameters. The addition of nanoparticles redistributes intermolecular interactions between particles of a liquid and leads to a shift of the equilibrium liquid - vapor line. To assess the thermodynamic behavior of nanofluids, we assume that liquids with small additions of nanoparticles satisfy the principle of the corresponding states [13]. From this, it follows that the regular and singular parts of the thermodynamic surface of the base fluid and the nanofluid coincide. It is assumed that equation is valid for both pure substance and nanofluid. The application of this equation is based on the principle of isomorphism. The scaling parameters obtained from the data for the pure substance were used to determine the critical parameters of the nanofluid. Because of the calculations, it was found that the position of the critical temperature for carbon dioxide $\left(T_{C}=\right.$ $304.13 \mathrm{~K})$ is shifted by $0.1 \mathrm{~K}$ in the range of volume concentrations of carbon nanotubes not exceeding $5 \%\left(T_{C n f}\right.$ $=304.27 \mathrm{~K})$. The accuracy of the algorithm was tested on the prediction of the parameters of the critical point of certain substances (ammonia, isobutane and toluene). The calculations showed the reproduction of data [16] with the accuracy of standard reference data.

To assess the reliability of the prediction of the critical point, the toluene - carbon nanotube system was considered. For this system, the fundamental equation of state of pure toluene in the reduced form [16] is known, and there are experimental data in the liquid phase far from the critical point [18]. Here we used the $P-\rho-T$ data for toluene with single-walled carbon nanotubes, whose diameter varies from 0.4 to $2 \mathrm{~nm}$, the length of the tubes in the range from 1 to $30 \mathrm{~nm}$ and the volume concentration of nanotubes $0.02 \mathrm{~g} / 1$ [18]. The shift of the critical temperature in the system of toluene + carbon nanotubes, calculated according to the algorithm

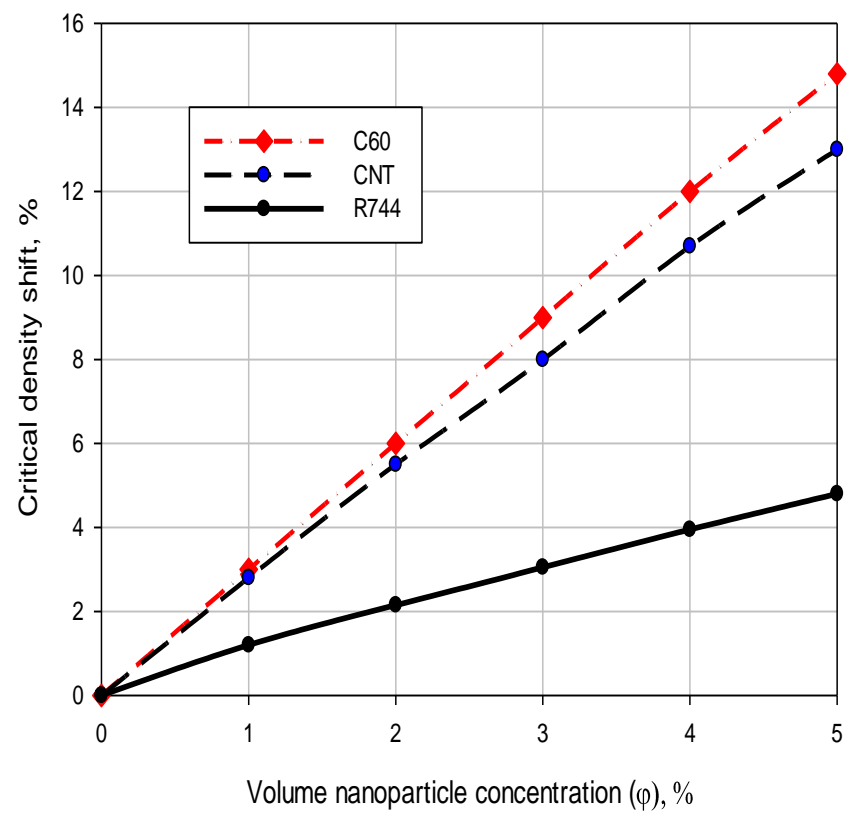

Figure 3 - Effects of $C N T$ and $C_{60}$ doping on position the carbon dioxide critical densities

developed, gives the value $\Delta T c \approx 0.2 \mathrm{~K}$ for bulk concentrations of $0.05 \%<\varphi<0.1 \%$. The results of the prediction make it possible to compare model calculations with experimental data from Bulavin et al. [18]. The behavior of various isotherms of pure toluene and nanofluid - toluene with carbon nanotubes. The accuracy of the description of the density according to the equation of state in the temperature range $290 \ldots 300 \mathrm{~K}$ is less than $0.1 \%$ in the liquid phase and indirectly confirms the reliability of the prediction of critical parameters and parameters of the critical point of some substances (ammonia, isobutane and toluene). The calculations showed the reproduction of data [16] with the accuracy of standard reference data. The shift of the critical point $\Delta T c=T_{c r f}-T_{c n f}$ in natural refrigerants with the addition of carbon nanotubes.

\section{Thermodynamic properties of the nanofluids}

The fundamental equations of state in reduced form [7], [8] are used to restore thermodynamic surface in vicinity of singular point. Compressibility factor $(Z)$ of nanofluid in the range $0 \quad \ldots \quad 5 \%$ volume concentrations $\varphi$ of nanoparticles $(n p)$ was found via scaled reference fluid properties

$$
Z=Z\left(\rho_{C n f} \rho, T / T_{C n f}\right) .
$$

Critical parameters of nanofluid $\left(\rho_{C n f}, T_{C n f}\right)$ were calculated from fundamental equation of state in vicinity of critical point. The density of nanofluid $(n f)$ was determined via reference fluid density $(r f)$ by standard approximation [14]:

$$
\rho_{n f}=(1-\varphi) \rho_{r f}+\varphi \rho_{n p}
$$

To estimate the nanofluid critical parameters an algorithm from [13] was applied. From the fundamental EoS for reference liquid the $p-\rho-T$ data in vicinity of 
critical point were generated to establish the fitting parameters in the power law equations [13]

$$
\frac{\rho_{\sigma}}{\rho_{c}}-1=N_{1}\left(1-\frac{T_{\sigma}}{T_{c}}\right) \pm N_{2}\left(1-\frac{T_{\sigma}}{T_{c}}\right)^{\beta}
$$

Here $\rho_{c}$ and $T_{c}$ are critical density and temperature; $N_{l}$, $N_{2}, \quad \beta$ are fitting parameters; $\rho_{\sigma}$ and $T_{\sigma}$ are density and temperature along saturation curve.

An equation is valid both reference liquid and nanofluids only in the critical domain. The fitting parameters in equation (3) were restored from the $\rho-T$ data for reference liquid and then used to estimate critical parameters of nanofluid. Reliability and accuracy of algorithm tested at limit $\varphi=0$ to reproduce the critical points of reference liquids. The results of our calculations reproduce the EoS data from [1] within experimental accuracy of density measurements for given substance.

Thermodynamic functions are calculated on the basis of algebraic transformations and the operation of differentiation according to standard relations for characteristic functions. Similarly, expressions for calculating enthalpy and entropy are found from the relationships given below.

A complete list of the calculated relations for thermodynamic functions according to the equation of state (1) - (12) is given in [16]. Ideal-gas functions and the coefficients of equation for $\mathrm{CO}_{2}$ are given in [18]. Algebraic expressions for calculating properties were programmed into MATLAB. Table 2 shows the results of calculations of the thermodynamic functions of R744 for various volume concentrations of the fullerenes and carbon nanotubes. The Appendix contains tables of thermodynamic properties of some technically important substances with various nanoparticle additives.

To calculate the thermodynamic properties, we used the models of simplified fundamental equations of state NIST (National Institute of Standards and Technologies) for 20 technically important substances developed in [15]. The equations of state are presented in the form of a superposition of the Helmholtz free energy for an ideal gas (index " 0 ") and interacting particles (index " $r$ "):

$$
a(\rho, T)=a^{0}(\rho, T)+a^{\mathrm{r}}(\rho, T)
$$

In the dimensionless form, the equation has the form

$$
\frac{a(\rho, T)}{R T}=\alpha(\delta, \tau)=\alpha^{0}(\delta, \tau)+\alpha^{\mathrm{I}}(\delta, \tau)
$$

where $\mathrm{R}$ is the universal gas constant, $\alpha$ is the dimensionless free energy of the Helmholtz, $\tau=T_{C} / T$ and $\delta=\rho / \rho_{C}$ are the dimensionless temperature and density.

The Helmholtz free energy of an ideal gas is determined by the enthalpy $(h)$ and entropy $(s)$ :

$$
a^{0}=h^{0}-R T-T s^{0}
$$

The functional form of the components of the dimensionless free energy of Helmholtz (5), proposed in [15], is written as follows:

$$
\begin{gathered}
\alpha^{0}=\frac{h_{0}^{0} \tau}{R T_{\mathrm{c}}}-\frac{s_{0}^{0}}{R}-1+\ln \frac{\delta \tau_{0}}{\delta_{0} \tau}-\frac{\tau}{R} \int_{\tau_{0}} \frac{c_{p}^{0}}{\tau^{2}} \mathrm{~d} \tau+\frac{1}{R} \int_{\tau_{0}} \frac{c_{p}^{0}}{\tau} \mathrm{d} \tau \\
\alpha^{\mathrm{I}}(\delta, \tau)=\sum N_{k} \delta^{i_{k}} \tau^{j_{k}}+\sum N_{k} \delta^{i_{k}} \tau^{j_{k}} \exp \left(-\delta^{l_{k}}\right)
\end{gathered}
$$

Thermodynamic functions are calculated because of algebraic transformations and the operation of differentiation according to standard relations for characteristic functions. For example, the pressure is calculated by the formula:

$$
Z=\frac{p}{\rho R T}=1+\delta\left(\frac{\partial \alpha^{\mathrm{T}}}{\partial \delta}\right)_{\tau}
$$

Similarly, expressions for calculating enthalpy and entropy are found from the relationships given below.

$$
\begin{gathered}
\frac{h}{R T}=\tau\left[\left(\frac{\partial \alpha^{0}}{\partial \tau}\right)_{\delta}+\left(\frac{\partial \alpha^{\mathrm{T}}}{\partial \tau}\right)_{\delta}\right]+\delta\left(\frac{\partial \alpha^{\mathrm{T}}}{\partial \delta}\right)_{\tau}+1 \\
\frac{s}{R}=\tau\left[\left(\frac{\partial \alpha^{0}}{\partial \tau}\right)_{\delta}+\left(\frac{\partial \alpha^{\mathrm{T}}}{\partial \tau}\right)_{\delta}\right]-\alpha^{0}-\alpha^{\mathrm{I}}
\end{gathered}
$$

As a system on which the approach to determining the thermodynamic properties of refrigerants with nanostructured materials is tested, a mixture of carbon dioxide - R744 with fullerenes and carbon nanotubes is considered. For the calculation of thermodynamic properties, the models of simplified fundamental equations of state NIST (National Institute of Standards and Technologies) for 20 technically important substances were used as the R744 with the addition of fullerenes and carbon nanotubes.

As follows from the results of calculations of thermodynamic properties, for small values of the volume concentration of nanotubes, their change can be neglected. A significant increase in the Joule - Thomson effect is observed at high concentrations of nanotubes and corresponds to an increase in the Joule - Thomson effect because of an increase in pressure. The critical parameters make it possible to calculate the thermodynamic properties based on the reduced equation of state [16]. One of the properties that is sensitive to the shape of the thermodynamic surface is the Joule - Thomson effect for refrigerants, where the main thermodynamic derivatives are present

$$
\begin{aligned}
& \mu R \rho=-\left(\delta \vartheta_{\delta}^{\tau}+\delta \vartheta_{\delta \delta}^{\tau}+\delta \tau \vartheta_{\delta \tau}^{\tau}\right) \\
& \left(1+\delta \varphi \vartheta_{\delta}^{\tau}-\delta \tau \vartheta_{\delta \tau}^{\tau}\right)^{2}-\tau^{2}\left(\vartheta_{\tau \tau}^{0}+\vartheta^{\tau}\right)\left(1+2 \delta \vartheta_{\delta}^{\tau}+\delta^{2} \vartheta_{\delta \delta}^{\tau}\right)
\end{aligned}
$$

A complete list of calculated relations for thermodynamic functions according to the equation of state (1) - (12) is given in [17]. The ideal-gas functions and the coefficients of equation for $\mathrm{CO}_{2}$ are given in [15]. Algebraic expressions for calculating properties were programmed into MATLAB. Table 2 shows the results of the thermodynamic functions of R744 for various volume concentrations of the fullerene and carbon nanotubes. 
Table 2 - The Joule - Thomson effect and thermodynamic properties of R744 with dopants of the fullerenes and carbon nanotubes

\begin{tabular}{|c|c|c|c|c|c|c|c|}
\hline $\begin{array}{c}\text { Temperature, } \\
K\end{array}$ & $\begin{array}{l}\text { Pressure, } \\
\mathrm{MPa}\end{array}$ & $\begin{array}{l}\text { Liquid Enthalpy (l) } \\
\mathrm{kJ} / \mathrm{kg}\end{array}$ & $\begin{array}{l}\text { Vapor Enthalpy (v) } \\
\mathrm{kJ} / \mathrm{kg}\end{array}$ & $\begin{array}{l}\text { Liquid Entropy (l) } \\
\mathrm{kJ} / \mathrm{kg}-\mathrm{K}\end{array}$ & $\begin{array}{l}\text { Vapor Entropy (v) } \\
\text { kJ/kg - K }\end{array}$ & $\begin{array}{l}\text { Liquid Joule-Thomson } \\
\mathrm{K} / \mathrm{MPa}\end{array}$ & $\begin{array}{c}\text { Vapor Joule-Thomson } \\
\mathrm{K} / \mathrm{MPa}\end{array}$ \\
\hline 250,00 & 1,7850 & 1046,0 & 46,644 & 147,71 & 437,04 & 0,80675 & 1,9641 \\
\hline 260,00 & 2,4188 & 998,89 & 64,417 & 169,44 & 435,92 & 0,88954 & 1,9144 \\
\hline 270,00 & 3,2033 & 945,83 & 88,374 & 192,41 & 432,56 & 0,97317 & 1,8626 \\
\hline 280,00 & 4,1607 & 883,58 & 121,74 & 217,30 & 425,94 & 1,0598 & 1,8050 \\
\hline 290,00 & 5,3177 & 804,67 & 171,96 & 245,63 & 413,75 & 1,1544 & 1,7341 \\
\hline 300,00 & 6,7131 & 679,24 & 268,58 & 283,38 & 387,08 & 1,2759 & 1,6215 \\
\hline
\end{tabular}

Volume concentrations $\varphi$ of the fullerenes $\quad \phi=1 \%$

\begin{tabular}{|c|c|c|c|c|c|c|c|}
\hline 250,00 & 1,7558 & 1048,3 & 45,850 & 146,60 & 437,05 & 0,80243 & 1,9667 \\
\hline 260,00 & 2,3846 & 1001,3 & 63,426 & 168,36 & 436,02 & 0,88550 & 1,9169 \\
\hline 270,00 & 3,1574 & 948,85 & 86,897 & 191,15 & 432,81 & 0,96866 & 1,8655 \\
\hline 280,00 & 4,5536 & 857,70 & 137,26 & 226,99 & 422,39 & 1,0926 & 1,7816 \\
\hline 290,00 & 5,2457 & 809,90 & 168,37 & 243,86 & 414,68 & 1,1486 & 1,7388 \\
\hline 300,00 & 6,6597 & 685,70 & 263,15 & 281,64 & 388,63 & 1,2704 & 1,6274 \\
\hline
\end{tabular}

Volume concentrations $\varphi$ of the fullerenes $\quad \phi=5 \%$

\begin{tabular}{|c|c|c|c|c|c|c|c|}
\hline 250,00 & 1,6216 & 1059,2 & 42,240 & 141,38 & 437,04 & 0,78191 & 1,9789 \\
\hline 260,00 & 2,2019 & 1014,4 & 58,199 & 162,42 & 436,49 & 0,86320 & 1,9303 \\
\hline 270,00 & 2,9283 & 964,03 & 79,686 & 184,71 & 433,95 & 0,94556 & 1,8800 \\
\hline 280,00 & 4,4046 & 867,58 & 131,23 & 223,34 & 423,80 & 1,0803 & 1,7905 \\
\hline 290,00 & 4,9719 & 829,27 & 155,39 & 237,18 & 417,98 & 1,1266 & 1,7561 \\
\hline 300,00 & 6,4938 & 704,28 & 247,79 & 276,54 & 393,00 & 1,2541 & 1,6442 \\
\hline
\end{tabular}

Volume concentrations $\varphi$ of the carbon nanotubes $\quad \phi=1 \%$

\begin{tabular}{|c|c|c|c|c|c|c|c|}
\hline 250,00 & 1,7097 & 1052,0 & 44,605 & 144,84 & 437,06 & 0,79552 & 1,9708 \\
\hline 260,00 & 2,3395 & 1004,5 & 62,126 & 166,92 & 436,15 & 0,88011 & 1,9202 \\
\hline 270,00 & 3,1095 & 952,00 & 85,373 & 189,82 & 433,06 & 0,96393 & 1,8685 \\
\hline 280,00 & 4,5040 & 861,00 & 135,23 & 225,77 & 422,87 & 1,0885 & 1,7846 \\
\hline 290,00 & 5,2012 & 813,10 & 166,19 & 242,77 & 415,24 & 1,1450 & 1,7417 \\
\hline 300,00 & 6,6358 & 688,50 & 260,82 & 280,89 & 389,30 & 1,2679 & 1,6299 \\
\hline
\end{tabular}

Volume concentrations $\varphi$ of the carbon nanotubes $\phi=5 \%$

\begin{tabular}{|c|c|c|c|c|c|c|c|}
\hline 250,00 & 0,89452 & 1128,5 & 23,312 & 106,67 & 434,61 & 0,63914 & 2,0647 \\
\hline 260,00 & 1,3652 & 1081,3 & 35,456 & 130,59 & 436,70 & 0,73875 & 2,0046 \\
\hline 270,00 & 2,0180 & 1028,0 & 53,041 & 156,15 & 436,83 & 0,83936 & 1,9446 \\
\hline 280,00 & 3,5072 & 926,00 & 98,390 & 200,58 & 430,75 & 1,0020 & 1,8440 \\
\hline 290,00 & 4,4104 & 867,20 & 131,46 & 223,48 & 423,74 & 1,0808 & 1,7902 \\
\hline 300,00 & 6,3222 & 721,70 & 233,74 & 271,58 & 396,96 & 1,2382 & 1,6599 \\
\hline
\end{tabular}




\section{Conclusions}

This work is one of the first attempts to calculate the thermodynamic properties of refrigerants with nanoparticle additives. Carbon dioxide was chosen as a basic substance as one of the promising natural refrigerants with minimal global warming potential. For the first time, detailed tables of the basic thermodynamic properties of the R744+ system of the fullerenes and carbon nanotubes are presented. An estimate of the phase equilibrium shift and the critical point showed that the effect of the fullerenes and carbon nanotubes hardly changes the thermodynamic behavior of the refrigerant at low volumetric concentrations of nanoparticles. More significant is the increase in the thermal conductivity of such systems, which requires nonequilibrium thermodynamic approaches.

The enormous potential of nanofluids for use in the new generation of cooling systems for microelectronics, laser technology and optoelectronics necessitates significant interdisciplinary efforts by specialists in the fields of refrigeration, organic and physical chemistry, materials science, spectroscopy, biology, physics, computer science, hydrodynamics. On the one hand, it is obvious that nanofluids can find wide application in a large number of applications. On the other hand, it is also clear that the commercial application of nanofluids is still at the very beginning. Therefore, fundamental research in this area broadens the horizons for the subsequent application of this promising class of substances in industry. This study is one of the first attempts to establish and demonstrate multiple links existing between the critical point shift in classical fluids and phase equilibria phenomena in mixtures embedded with nanostructured materials. From the very beginning of these efforts, the obtained results serve very useful information for scientists and engineers working in the field of emerging nanotechnology applications. The examples the critical point shift for $\mathrm{CO}_{2}$ with different types of nanoparticle doping: graphene genealogic tree (CNT, fullerenes) are given. There is no doubt that extension of our knowledge about thermodynamic and phase behavior of nanofluids will lead to the creation of reliable engineering recipes for solving the actual problems of nanotechnologies.

\section{References}

1. Angayarkanni SA., Philip J. 2015 Review on thermal properties of nanofluids: Recent developments. Advances in Colloid and Interface Science 225, p. 146-176

2. S.M. Sohel Murshed, C.A. Nieto de Castro, M.J.V. Lourenc, M.L.M. Lopes, F.J.V. Santos, 2011. A review of boiling and convective heat transfer with nanofluids, Renewable and Sustainable Energy Reviews 15. 23422354.

3. S. Kakaç, A. Pramuanjaroenkij. 2009. Review of convective heat transfer enhancement with nanofluids, International Journal of Heat and Mass Transfer 52. 3187 3196.
4. W. Yu, D. France, J. Routbort, S. Choi. 2008. Review and comparison of nanofluid thermal conductivity and heat transfer enhancements, Heat Transfer Engineering 29 (5). 432-460.

5. S.K. Das, S.U.S. Choi, H.E. Patel. 2006. Heat transfer in nanofluidsda review, Heat Transfer Engineering 27 (10). 3-19.

6. R. Saidura, K.Y. Leong, H.A. Mohammad. 2011. A review on applications and challenges of nanofluids. Renewable and Sustainable Energy Reviews 15. 16461668.

7. L. Wang, J. Fan. 2011. Toward nanofluids of ultrahigh thermal conductivity. Nanoscale Research Letters 6. 153.

8. S. Özerinç, S. Kakaç, A.G. Yazıcıoglu. 2010. Enhanced thermal conductivity of nanofluids - a state-ofthe-art review, Journal of Microfluidics and Nanofluidics 8 . $145-170$.

9. J.A Keblinski, D.G. Eastman, Cahill. 2005. Nanofluids for thermal transport. Materials Today 8. 3644.

10. Xiang-Qi Wang, A.S. Mujumdar. 2007. Heat transfer characteristics of nanofluids: a review, International Journal of Thermal Sciences 46. 1-19.

11. S.U.S. Choi, Z.G. Zhang, P. Keblinski. 2004. Nanofluids, in: H.S. Nalwa (Ed.), Encyclopedia of Nanoscience and Nanotechnology, vol. 6, American Scientific, Los Angeles, Calif, USA, p. 757-773

12. I.M. Mahbubul, R. Saidur, M.A. Amalina. 2012. Latest developments on the viscosity of nanofluids, International Journal of Heat and Mass Transfer 55. 874 885.

13. D. Nikitin, V. Mazur. 2012. Thermodynamic and phase behaviour of fluids embedded with nanostructured materials, International Journal of Thermal Sciences doi:10.1016/j.ijthermalsci.2012.02.021

14. V. Vasu, K. Rama Krishna, A.C.S. Kumar. 2008. Analytical prediction of thermophysical properties of fluids embedded with nanostructured materials, International Journal of Nanoparticles 1. 32-49.

15. E.W. Lemmon, R. Span. 2006. Short fundamental equations of State for 20 industrial fluids, Journal of Chemical and Engineering Data 51. 785-850.

16. E. Lemmon, M. Huber, M. McLinden. 2013. NIST Reference Fluid Thermodynamic and Transport Properties - REFPROP. Version 9.1.- Boulder: NIST.

17. E. W. Lemmon, R. T. Jacobsen, S. G. Penoncello, D. G. Friend. 2000. Thermodynamic Properties of Air and Mixtures of Nitrogen, Argon, and Oxygen From 60 to 2000 $\mathrm{K}$ at Pressures to $2000 \mathrm{MPa}$. J. Phys. Chem. Ref. Data 29. 331-385.

18. Yu Prylutskyy, S. Durov, L. Bulavin et al. 2001. Structure and Thermophys-ical Properties of Fullerene C60 Aqueous Solutions International Journal of Thermophysics, . 22, No. 3. 